Cell Tissue Res (1988) 253:267-269

\title{
Zymogen granules of mouse parotid acinar cells are acidified in situ in an ATP-dependent manner
}

\author{
Robert C. De Lisle*, Robin Steinberg, and John A. Williams \\ Cell Biology Laboratory and Department of Medicine Mount Zion Hospital, and the Departments of Physiology and Medicine, \\ University of California, San Francisco, USA
}

\begin{abstract}
Summary. The mechanism for acidification of zymogen granules in acinar cells of mouse parotid gland was explored using acridine orange, lysosomotropic agents, and an inhibitor of cellular ATP production. Methylamine and monensin reversibly collapsed the $\mathrm{pH}$ gradient of granules without affecting cellular ATP levels. Depletion of cellular ATP with antimycin $\mathrm{A}$ did not collapse the $\mathrm{pH}$ gradient. However, recovery of acidity in the granules, after collapse of the $\mathrm{pH}$ gradient by methylamine, was blocked by depletion of cellular ATP. These results demonstrate that zymogen granules of parotid gland are acidic in situ and that ATP is required for acidification of the granules.
\end{abstract}

Key words: Parotid gland - Acidification - Zymogen granule - Lysosomotropic agents - Acridine orange - Mouse (Swiss Webster)

Most endocrine and neuroendocrine secretory granules are actively acidified in situ (for review, see Rudnick 1986). The molecular mechanism responsible for acidification of granules is an $\mathrm{H}^{+}$-ATPase (or proton pump), which may also be found in the trans Golgi. Recently, the finding of actively acidified granules has been extended to include secretory granules in an exocrine gland, the pancreas (Niederau et al. 1986; De Lisle and Williams 1987). In this report we demonstrate that the secretory granule of another exocrine gland, the parotid, is also acidic and that acidification in situ is ATP-dependent.

\section{Materials and methods}

Parotid glands from mice $(20-25 \mathrm{~g}$ male Swiss Webster strain, Simonsen, Gilroy, CA) were dissociated into small groups of acinar cells by enzymatic digestion, divalent cation chelation, and mechanical shearing (Williams et al. 1978; De Lisle and Williams 1987). Dissociated acinar cells were incubated at $37^{\circ} \mathrm{C}$ with $25 \mu \mathrm{M}$ acridine orange (Eastman Kodak, Rochester, NY) in HEPES-buffered Ringer solution, $\mathrm{pH} 7.4$, supplemented with nutrients and equilibrated with $\mathrm{O}_{2}$ (Williams et al. 1978; De Lisle and Williams 1987). Acridine orange is a weak base which will accumulate in acidic cellular compartments. This dye also has the property of being fluorescent, emitting green light at low concen-

\footnotetext{
* Present address and address for offprint requests: R.C. De Lisle, Ph.D., Department of Physiology, University of Michigan, Medical School, Ann Arbor, MI 48109, USA
}

trations and orange light when concentrated (Lee et al. 1982). The cells accumulated acridine orange and, observed by epifluorescence microscopy with a fluorescein filter, displayed green cytoplasm, yellow-green nuclei, and orange zymogen granules similar to that previously demonstrated for pancreatic acinar cells (Niederau et al. 1986; De Lisle and Williams 1987). To document this pattern with black and white photography, a rhodamine filter block was used which removes most of the green fluorescence while allowing orange light to pass. Acridine orange-loaded acidic compartments appear as bright spots in a dark surrounding cytoplasm. Paired fluorescent and bright field micrographs were made to demonstrate the location of fluorescent areas within the cells.

ATP was extracted from cells by perchloric acid precipitation and measured by luminescence with a luciferase assay (Kimmich et al. 1975). Protein was measured by the method of Bradford (1976).

\section{Results}

Parotid glands were dissociated into small groups of cells that retained their attachment to each other at their apical poles (Figs. 1-6b). The cells also retained the polarity of their cytoplasm, with zymogen granules clustered around the acinar lumen and the nuclei located basally. In acridine orange-loaded parotid acinar cells, the area that corresponded to the location of zymogen granules (Fig. 1 b) was labeled fluorescently (Fig. 1 a).

To test whether the fluorescence of granules was due to dye-binding, the ability of lysosomotropic (acidotropic) agents (such as methylamine and monensin) to dissipate the fluorescence was examined. Methylamine is a weak base and will collapse $\mathrm{pH}$ gradients by equilibrating across membranes and binding protons. The ionophore monensin collapses $\mathrm{pH}$ gradients in a different manner, by catalyzing the electroneutral exchange of cations for protons. Both of these agents abolished the fluorescence of zymogen granules (Figs. 2 and 3). Since mitochondrial ATP production involves a proton gradient, and acidification of granules in other cells is ATP-dependent (Rudnick 1986; Niederau et al. 1986), ATP levels were determined in cells treated with methylamine or monensin. Neither lysosomotropic agent had any effect on cellular ATP levels (Table 1).

The effect of lysosomotropic agents on fluorescence of zymogen granules was reversible by washing the cells in the absence of the agent. As seen in Fig. 4, washing and reincubating the cells in acridine orange-containing medium 

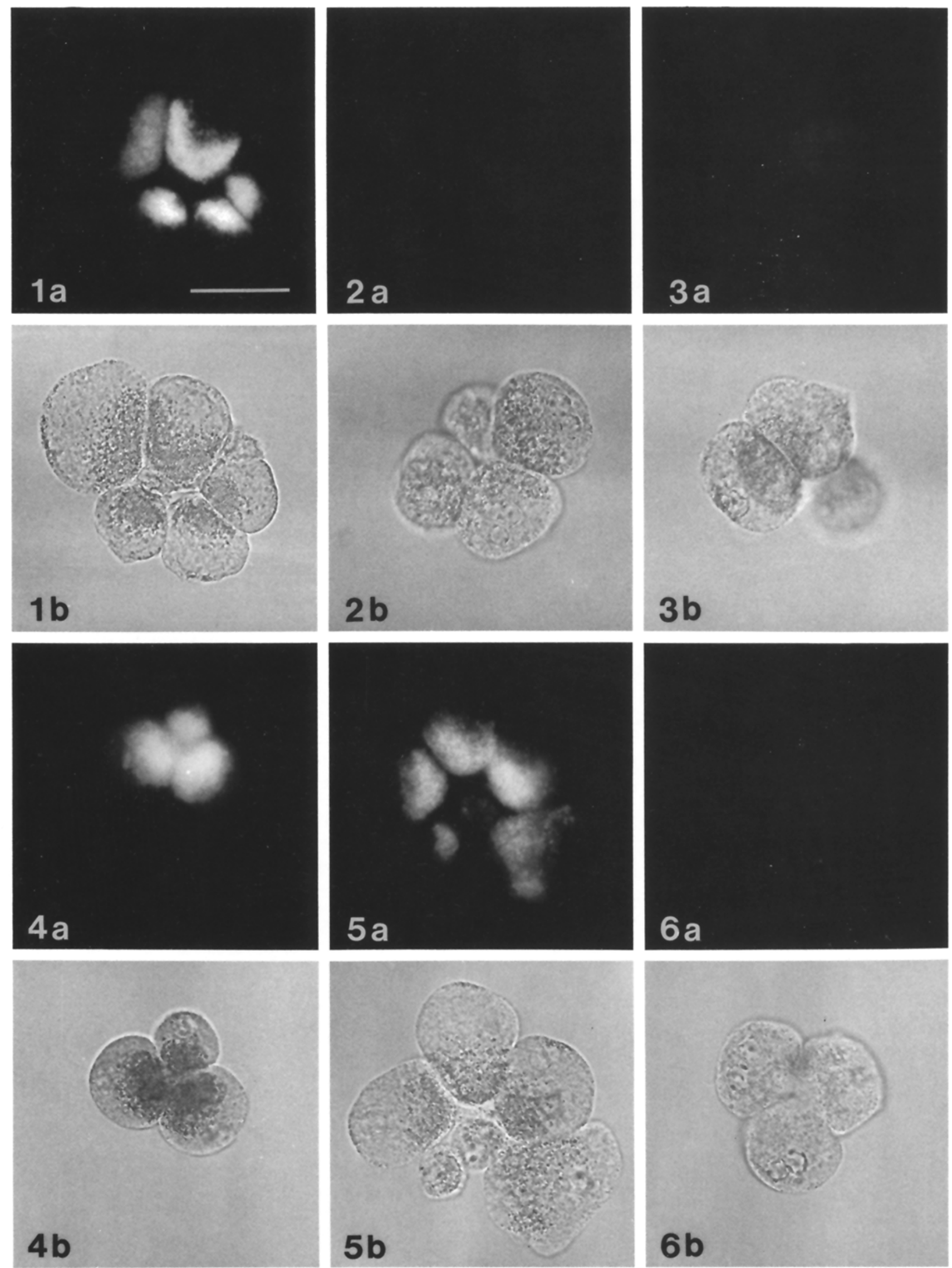

Figs. 1-6. Paired fluorescent $(a)$ and bright field $(b)$ micrographs of acridine orange-loaded parotid acinar cells. Cells loaded with $25 \mu \mathrm{M}$ acridine orange for $15 \mathrm{~min}$. Acridine orange present under all conditions and cells kept at $37^{\circ} \mathrm{C}$ in oxygenated HEPES-buffered Ringer solution. $(\times 590 ;$ bar $=30 \mu \mathrm{m})$ Fig. 1 Control. Fig. 2 After $15 \mathrm{~min}$ incubation with $30 \mathrm{mM}$ methylamine. Fig. 3 After 15 min incubation with $3 \mu \mathrm{M}$ monensin. Fig. 4 After $15 \mathrm{~min}$ incubation with $30 \mathrm{mM}$ methylamine followed by washing in absence of methylamine. Fig. 5 After $15 \mathrm{~min}$ incubation with $10 \mu \mathrm{M}$ antimycin A. Fig. 6 After $15 \mathrm{~min}$ incubation with $30 \mathrm{mM}$ methylamine followed by washing in absence of methylamine with $10 \mu \mathrm{M}$ antimycin $\mathrm{A}$ 
Table 1. ATP levels of parotid acinar cells treated with lysosomotropic agents or the mitochondrial electron transport inhibitor antimycin A

\begin{tabular}{ll}
\hline Treatment & ATP (nmol/mg cell protein) \\
\hline Control & $14.0 \pm 1.8$ \\
Methylamine, $30 \mathrm{mM}$ & $14.1 \pm 2.0$ \\
Monensin, $3 \mu \mathrm{M}$ & $13.7 \pm 1.9$ \\
Antimycin A, $10 \mu \mathrm{M}$ & $0.9 \pm 0.3^{*}$ \\
\hline
\end{tabular}

Parotid cells incubated in oxygenated HEPES-buffered Ringer solution for $30 \mathrm{~min}$ at $37^{\circ} \mathrm{C}$ in presence of indicated agent. ATP and protein measured as described in Methods. Data represent means \pm standard errors from three independent experiments. ( ${ }^{*} P<0.001$ by one-way analysis of variance compared to control)

without methylamine resulted in zymogen granules becoming fluorescent again, indicating their reacidification.

To determine whether acidification of granules was dependent on ATP, as is the case for other secretory granules, the mitochondrial electron transport inhibitor antimycin A was used to deplete cellular ATP. By itself, antimycin A had little effect on fluorescence of zymogen granules (Fig. 5) even though cellular ATP levels were less than $50 \%$ of normal within $2 \mathrm{~min}$, and about $6 \%$ of normal by $15 \mathrm{~min}$ with no further decrease up to $30 \mathrm{~min}$ (Table 1). No decrease in fluorescence of granules was seen for as long as $45 \mathrm{~min}$ in the presence of antimycin A (not shown). Recovery of the granule's $\mathrm{pH}$ gradient was dependent on cellular ATP. If the $\mathrm{pH}$ gradient was first collapsed with methylamine as in Fig. 2, after which the cells were washed in the presence of antimycin $\mathrm{A}$, the granules did not become fluorescent again (Fig. 6).

\section{Discussion}

The fluorescent pattern of acridine orange-loaded parotid acinar cells demonstrates that the zymogen granules are acidic with respect to the cytoplasm. As expected, the $\mathrm{pH}$ gradient of granules can be collapsed with a weak base (methylamine) or a cation ionophore (monensin). That two agents which act in different ways were effective in dissipating the granular fluorescence constitutes an argument that the acridine orange accumulation in the granules was due to a $\mathrm{pH}$ gradient, and not to nonspecific dye-binding to granule contents. Maintenance of the $\mathrm{pH}$ gradient did not require cellular ATP (at least over a $45 \mathrm{~min}$ period). That ATP depletion alone had no effect on intragranular $\mathrm{pH}$ can be explained by the low $\mathrm{H}^{+}$permeability of the granule membrane (Arvan et al. 1984; De Lisle 1984). However, once collapsed, recovery of the $\mathrm{pH}$ gradient is ATP-dependent. This observation is consistent with the presence of a inwardly-directed $\mathrm{H}^{+}$-ATPase in the granule membrane, as is the case in other secretory granules (Rudnick 1986).

It has been reported previously that zymogen granules of the parotid gland are not acidic by the acridine orange technique (Arvan et al. 1984). In that report, acridine orange was used at a very low concentration $(1.5 \mu \mathrm{M})$, which we found to be too low to label granules fluorescently in parotid gland acinar cells. At lower concentrations of acridine orange there were a few fluorescent spots (not shown), but they were not clustered around the apical poles of the cells. These fluorescent spots which label at lower concen- trations of acridine orange probably represent lysosomes and condensing vacuoles, which are much less abundant compared to secretory granules, and are also highly acidic (Rudnick 1986; Orci et al. 1987).

The relatively high concentration of acridine orange found to be necessary to label granules suggests that the granules are not as acidic as lysosomes $(\mathrm{pH}<5)$, which do label with low concentrations of acridine orange (Rudnick 1986). In a recent study using an electron microscopic probe of organellar $\mathrm{pH}$, it was reported that pancreatic and parotid zymogen granules were not detectably acidic (Orci et al. 1987). The technique used in that study relied on faithfully retaining the probe in the various cellular compartments throughout fixation, dehydration, and embedding for electron microscopy. Therefore, it may be expected to be less sensitive than acridine orange, which is used on intact, living cells.

The data presented here for parotid acinar cells, along with those for exocrine pancreas (Niederau et al. 1986; De Lisle and Williams 1987), demonstrate that acidification of secretory granules is a common feature of exocrine glands and is not restricted to endocrine and neuroendocrine tissues. The functional significance of acidification of exocrine secretory granules remains to be established, but it may serve to keep the secretory proteins in a condensed and inert state until secreted (De Lisle and Hopfer 1986).

Acknowledgments. This work was supported by NIH grant DK 32994, a fellowship from the Cystic Fibrosis Foundation (R.C.D.), and the Elise Stern Haas Fund of Mount Zion Hospital.

\section{References}

Arvan P, Rudnick G, Castle JD (1984) Osmotic properties and internal $\mathrm{pH}$ of isolated rat parotid secretory granules. J Biol Chem 259:13567-13572

Bradford MM (1976) A rapid and sensitive method for the quantitation of microgram quantities of protein utilizing the principle of protein-dye binding. Anal Biochem 72:248-254

De Lisle RC (1984) Electrolyte Transport Properties of Pancreatic Zymogen Granules (PhD Thesis). Cleveland, $\mathrm{OH}$ : Case Western Reserve University

De Lisle RC, Hopfer U (1986) Electrolyte transport properties of pancreatic zymogen granules: implications for pancreatic secretion. Am J Physiol 250:G489-G496

De Lisle RC, Williams JA (1987) Zymogen granule acidity is not required for stimulated pancreatic protein secretion. Am J Physiol 253:G711-G719

Kimmich GA, Randles J, Brand JS (1975). Assay of picomole amounts of ATP, ADP and AMP using the luciferase enzyme system. Anal Biochem 69:187-206

Lee HC, Forte JG, Epel D (1982) The use of fluorescent amines for the measurement of $\mathrm{pH}_{\mathrm{i}}$ : Applications in liposomes, gastric microsomes, and sea urchin gametes. In: Deamer DW (ed) Intracellular pH: Its Measurement, Regulation, and Utilization in Cellular Functions. A Liss, New York, pp 135-160

Niederau C, Van Dyke RW, Scharschmidt BF, Grendell JH (1986) Rat pancreatic zymogen granules: an actively acidified compartment. Gastroenterology $91: 1433-1442$

Orci L, Ravazzola M, Anderson RGW (1987) The condensing vacuole of exocrine cells is more acidic than the mature secretory granule. Nature 326:77-79

Rudnick G (1986) ATP-driven $\mathrm{H}^{+}$pumping into intracellular organelles. Ann Rev Physiol 48:403-413

Williams JA, Korc M, Dormer RL (1978) Action of secretagogues on a new preparation of functionally intact, isolated pancreatic acini. Am J Physiol 235:E517-E524

Accepted January 27, 1988 